\title{
Multimedia technologies and online task-based foreign language teaching-learning
}

\author{
Ana Maria de Jesus Ferreira Nobre* \\ doi: http://dx.doi.org/10.18543/tjhe-5(2)-2018pp75-97
}

Received: 09.05.2018

Accepted: 28.05.2018

\begin{abstract}
Teaching and learning a foreign language at a distance implies many challenges, namely regarding oral skills. At Universidade Aberta (the Portuguese Open University), and taking into account its virtual pedagogical model (Pereira, 2007) and the Common European Framework of Reference for Languages (Alves, 2001), we suggest curricular paths which include online communicative practices, both oral and written, within the present pedagogical offer, following a studentcentred, task-oriented approach. Thus, in this text, we share some examples of training activities in German, French and English, focusing on oral practice, and based on digital resources. These digital resources comprise multimedia materials, either produced by the teachers or the students, as well as other materials available on the web 2.0. Our teaching and research practice within the field of foreign languages and in e-learning, in particular, leads us to conclude that the multimedia resources used are suitable for the online teaching and learning of foreign languages (see third question of questionnaire), especially for professionally engaged adults, as is the case with Universidade Aberta's students, providing them with real-life situations that foster the teaching-learning of languages in the virtual environment. We include responses to a questionnaire survey filled out by a group of students.
\end{abstract}

Keywords: task-based teaching and learning; foreign languages; online communicative practices; multimedia resources; e-learning.

* Ana Maria de Jesus Ferreira Nobre (Ana.Nobre@uab.pt), PhD, works at the Education Department, Universidade Aberta (Portugal), where she teaches foreign languages.

More information about the author is available at the end of this article (after the bibliography list). 


\section{Introduction}

Universidade Aberta (UAb), a pioneering institution in distance higher education in Portugal, has significantly contributed to the training of adults at higher level for a decade, and has been the first and only (state) university in Portugal teaching all of its courses (under-graduate, post-graduate, and lifelong learning) in the e-learning system, using a unique Virtual Pedagogical Model (Pereira et al., 2007). UAb has made a strong commitment to innovation and to the quality of its educational offer, including foreign languages, to respond to the multiple challenges we currently face. Among these challenges, first and foremost is the conciliation of the demands of online foreign language teaching/learning with a specific virtual pedagogical model (Pereira et al., 2007) within the current context of e-learning. We must reflecting on how to teach foreign languages - English, German and French - following a student-centred model; on how to teach oral skills in distanceteaching mode. In this article, we shall try to answer these questions resorting to our experience as teachers of foreign languages and as researchers in the fields of foreign language education, distance education, and e-learning.

\section{Background}

One of the many concepts and challenges that the digital environment/ technology poses to pedagogy is the complexity of monitoring learning in the digital age.

Bringing together teaching/learning and digital technologies challenges us to rethink both terms, firstly, because affects the teaching of foreign languages in online mode and, secondly, because the terms "e-learning teaching/learning" and "digital" imply a contemporary understanding of both terms and this is transforming education today.

Moreover, the two terms are polysemic. For example, learning can be synonymous with mediation, and may refer to a very special mediation, defined in the field of educational sciences as a practice that is always connected to student autonomy (Boutinet, 2003), centred on the individual, and accompanied by social issues (Paul, 2004).

However, the fact that we speak of "teaching / learning" is an indicator of the shift from the classical model of education, centred on the transmission of knowledge, to a type of teaching / learning carried out by the students themselves', in gradual and varied ways (guidance, tutorials, etc.). We therefore observe a change in the educational paradigm, as well as a diversity and plurality of teacher and student practices. 
To include digital technologies in teaching / learning does not simply imply integrating digital resources in the existing education system, but means contributing to the transformation of the education paradigm.

The polysemic character of teaching/learning foreign languages with multimedia technology within the distance-learning network corresponds to a proliferation in the use of digital resources. We would like to hereby dwell on some aspects (Barbot and Jacquinot-Delaunay, 2008: 159-163):

- a synchronous illustrative use by the teacher, through access to a server (the same space, same time, same activity for all)

- a complementary, previously-defined, synchronous use (same space, different pace, same activities)

- a previously-defined, asynchronous use (same space, different pace, equal activities)

Thus, the use of digital resources in teaching-learning shows a certain gradation in the transformation of training activities (Barbot \& JacquinotDelaunay, 2008: 167):

- Digital "educational" resource: as an illustration of an activity learning support;

- The autonomy given to the student, from the choice of space or time to the type of activity.

However, underlying the issue of being able to learn is the question of resource accessibility. The issue of being able to learn is linked to the issue of knowing how to learn. It is not necessarily because a training activity linked to a digital resource is available that learning will ensue. This implies the need to provide technological guides and tutorials to understand the activity, do the task, and ensure effective access to other knowledge construction methods.

\section{The Universidade Aberta model}

Universidade Aberta has been dedicated to higher distance education since it was founded in 1988. In the national context, it remains a pioneer institution, as it is the first and only (state) university in Portugal, whose entirety of courses are taught entirely online, through Moodle, an online platform for distance learning, which has constantly been subject to specific updates by a Universidade Aberta team of specialists. 
With the implementation of Universidade Aberta's Virtual Teaching Model for the university of the future, in 2007, the teaching and learning of foreign languages started to envisage aspects that traditional distance teaching did not fully explore. Conceptually, that model embodies four main principles, as described below (Pereira et al., 2007):

1. The principle of student-centred learning, where the student plays an active role in the construction of knowledge.

2. The principle of digital inclusion, which favours strategies of digital literacy skills, therefore providing access to modern means of communication and networking.

3. The principle of flexibility, which advocates a personal and individual management of the learning process, both in terms of time and of space.

4. The principle of interaction, whereby different types of interaction are present, particularly the written one, but always asynchronous, all potentiating collaboration.

The interaction is of great importance as it guides, in part, the curricular design of existing courses.

To be more specific, each course of the 1st cycle degree course is based on teaching-learning paths generally composed of a set of training activities, followed by evaluation activities. There are, therefore, various moments of learning complemented by different types of interaction (e.g. between the student and the learning content; student to student; professor to student). These interactions take place in different learning forums with complementary features and purposes. That is, in the virtual classroom there are spaces provided for students to interact with their classmates - student-moderated forums - and spaces where the student/s interacts/interact with the teacher teacher-moderated forums.

This is thus, primarily, an asynchronous pedagogical model, which values the availability of the learner, and as such, is perfectly suited to the typical profile of the student of Universidade Aberta: adult students who resume their studies at a higher level and that, having a full personal and professional life, need to access contents and learning activities without spatiotemporal constraints.

\section{Student-centered learning and digital inclusion}

Autonomy is a complex concept and is open to various interpretations (Bailly, 2010; Chateau \& Bailly, 2013). For Holec (1990), autonomy is 
defined as an active practice, the responsibility of which belongs to the student; it is necessary to develop the ability to learn to be able to make all the decisions inherent in learning a language. For Little (2000), autonomy implies the intervention of metacognition; it involves detachment, independent action, and reflexivity. Rivens Mompean (2012) speaks of linguistic and learning autonomy. Linguistic autonomy affects the autonomy of learning, and contributes to overall autonomy.

As far as we are concerned, all these definitions are valid because we consider autonomy as a multifaceted set, both as regards individual responsibility, and the learning environment where it takes place. Whichever the definition chosen, autonomy is not innate (Holec, 1990), but is the result of a process (Portine, 1998).

In this teaching methodology, the student / learner is the social actor and the primary agent of his / her learning and the virtual classroom is the social space for learning and interacting.

Therefore, a legitimate question arises: how is this virtual model implemented in the teaching-learning of foreign languages online?

\section{Teaching-learning foreign languages online}

With the implementation of the new virtual pedagogical model, teaching and learning foreign languages at the Universidade Aberta began to envisage other aspects that traditional distance teaching had not totally explored, namely orality - oral comprehension and production. Traditional distance teaching, allow written and oral comprehension (cassettes) and written production; virtual teaching introduces oral production and written and oral interaction. Thus, with current ICT, one of our mottos, which consists of teaching-learning "anywhere in the world", has taken on a new dimension.

We have, therefore, been designing, analyzing and testing new strategies, such as, for example, training and evaluation activities (Pereira et al., 2007), to systematically and continuously develop competencies of oral comprehension and production, over each semester, in the German, French and English languages. These are the objectives and the focus of research in the current project “@ L2L - Open Language Teaching and Learning” and, there were in the previous project "Teaching/Learning Foreign Languages online", both coordinated by Professor Ana Nobre, underway at Universidade Aberta's Distance and E-Learning Education Laboratory and Research Centre (LE @ D).

These foreign languages are included in the curriculum of formal 1st cycle courses on offer in our institution, as well as in Lifelong-Learning 
courses. The following foreign languages, from level I to level VI, are included in the syllabus of the Degree Programs in Linguas, Literaturas $e$ Culturas - Variante de Línguas Estrangeiras, Linguas Aplicadas, Estudos Europeus, Humanidades and História: German, Spanish, French and English. In the first semester the odd levels (I, III, V) are given and, in the second semester, the even levels (II, IV, VI). They are taught in accordance with the competencies set out in the Council of Europe's (2011) Common European Framework of Reference for Foreign Languages (CEFR), which are divided into six levels (see Table 1).

\section{Table 1}

Correspondence between the foreign language level on offer at UAb and the guidelines of CEFR

\begin{tabular}{|l|l|}
\hline \multicolumn{1}{|c|}{ UAb Curricular Unit } & \multicolumn{1}{c|}{ CEFR Level } \\
\hline Foreign language I and II & Level A2 / B1 \\
\hline Foreign language III and IV & Level B2 \\
\hline Foreign language V and VI & Level C1 \\
\hline
\end{tabular}

Among the results of the first project "Teaching / Learning Foreign Languages online" and in addition to the adaptation of the principles of the new virtual pedagogical model and the CEFR to the teaching/learning of languages, we integrated multimedia technologies appropriate to this context.

One of the main difficulties in adding multimedia technologies to the teaching / learning process comes from an inextricable number of educational issues and the unavoidable technical considerations that accompany them. Adherence to a tool (Moodle and other online tools) necessarily involves the acquisition of some technical skills and its use should involve a theoretical model. Any perspective of educational innovation cannot be considered without the knowledge of the technology options we adopt. There are as many ways to integrate technology into a foreign language virtual classroom as there are users / students. Technologies, in their flexibility, have the versatility of all inventions. When adding to the range of "products" already existing in teaching, we must decide upon their pedagogical relevance: just as the action-oriented approach does not replace the communicative approach in teaching foreign languages, the introduction of multimedia technologies is not a substitute for other tools, but makes teaching / learning more central and efficient. 
In view of these considerations, we would like to outline the following principles and purposes involved in this teaching:

1. To enable the teaching: learning is promoted when students put into practice their new knowledge, based on their previous experiences.

2. To demonstrate skills: learning is promoted when students observe the competencies they will learn.

3. To apply competencies: learning is promoted when students apply their competencies (including those newly acquired) to the solving of problems.

4. To integrate competencies in real-world activities: learning is promoted when students reflect upon and use their acquired competencies.

\section{V.1. Enabling experiencing and demonstrating skills}

Over the past decade, one of the essential branches of the research activities carried out within the language projects at Universidade Aberta has been the introduction of digital activities that promote student autonomy and their accessibility from any multimedia device. We can summarize the features of task-based teaching as follows:

- A collective dimension: the student is also a social actor.

- Realistic or "real-life" situations (imaginary situations or make-believe situations are almost non-existent).

- Immediate and collective decision-making.

- The assessment is not only carried out on the criteria (linguistic, pragmatic, and sociocultural) involved in the transmission of information, but also on the accomplishment of the task itself.

The usefulness of technology to support teaching/learning has been demonstrated (Chapelle, 2006), although, of course, there is no automatic link between ICT and pedagogical practices (Debaisieux \& Boulton, 2006).

As we are not willing to burden our students with additional financial costs, we promote the use of free digital tools as much as possible (Nobre \& Cardoso, 2015). An example of this strategy is the use of podcasts and showcasts. 
Podcasts are short digital audio files, easy to produce and available online, which can be listened to and downloaded to devices, such as computers or mp3 players, among others (Moura, 2006).

With regard to showcasts, we must start by observing that this term has emerged during our search for solutions to implement oral production, and to minimise the spatio-temporal distance between teachers and students; they are not vodcasts or screencasts. A showcast still differs from enhanced podcasts, which also combine audio and image, because a showcast specifically designates a PowerPoint document for teaching purposes that integrates text, image and audio/video.

Anticipating the advantages in the use of digital technologies in different contexts and levels of education, particularly in foreign language distance and e-learning education at higher level, and prior to dwelling on their representative excerpts, we would like to mention that we provided tutorials with instructions and examples, in the foreign language curricular units (CUs) on offer at UAb, in order to foster independent learning by the students. Given the heterogeneous profile of our students, these tutorials (figure 1) also ensure that even those who are less familiar with Web 2.0 tools perform the tasks requested in the target language, since this is the object of teaching and learning (and not the acquisition of skills in digital technologies).

Figure 1

Tutorial (sound recording)

Procedimentos para gravar/nncluir som (Office 2007):

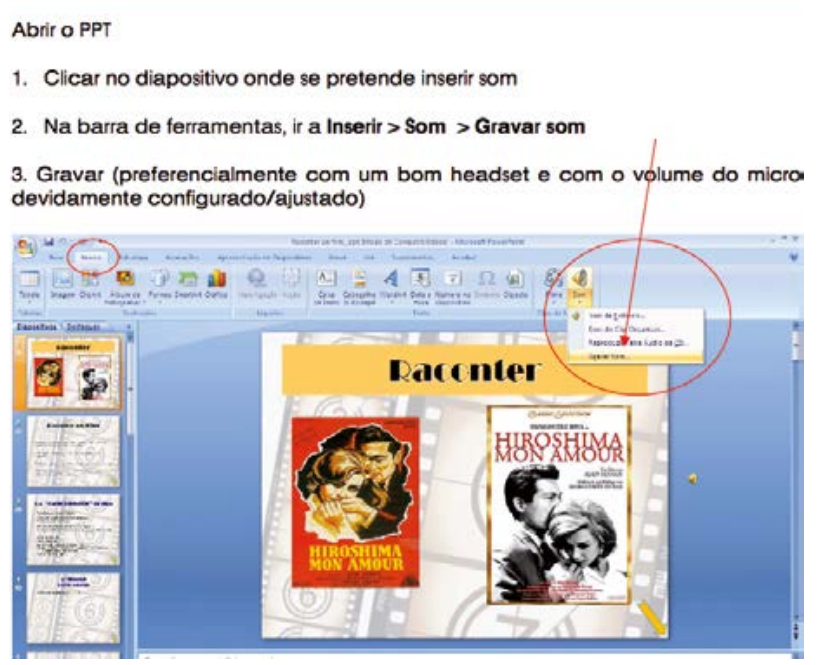


Throughout the semester, students engage in multiple asynchronous activities to practise orality (speaking and listening skills) by following this tutorial, or by producing these activities using other technological tools.

\section{V.2. Applying competencies and integrating competencies in real-world activities}

Although the specifics and challenges of online foreign language teaching are multiple, in this article, we give particular attention to those referring to oral comprehension and expression, in the context of UAb's educational offer. In this case, the learning activities and interactions (between students, between students and teachers, and between students and content), and part of the continuous assessment (which corresponds to $40 \%$ of the final mark) are carried out through the Moodle platform, which, due to its versatility, has become widely used in Portugal and other countries, at different levels of education.

The Moodle platform in use at UAb is customized and supplemented either by current and universal computer tools (such as Word and PowerPoint, or their open-source equivalent) or by other more specific ones (for example, Windows Sound Recorder or Audacity - the latter rather more complete) to record audio files. In specific synchronous communication situations (audio and video) Colibri is used, as it is directly integrated into the Moodle platform itself, or alternatively, the popular Skype, with the obvious drawback that it requires the opening of an account prior to use. The video resource has also been used to meet the interests and expectations of our students, who are all adults. Thus, by way of illustration, we shall highlight some of the multimedia resources, the use of which has been encouraged to carry out training and assessment activities during the academic year, and we shall as well mention the main didactic principles underlying them:

- Vodcasting: Learning through a new kind of cinema, a new relationship with knowledge.

- YouTube: A source of current and open learning.

- Still images or animation sequences: Learning with a more realistic dimension.

- Free digital tools, podcasts, videocasts and showcasts (Cardoso et al., 2013): Learning that encourages the active student to participate in his/ her own knowledge construction.

Now, we focus on specific tasks in each of the three languages. 


\section{V.2.1. German language curricular units}

The first A1 level German course for complete beginners was established in the academic year of 2017/2018 (previously the course was taught at B1 level), and started to address students without previous knowledge of German. Teaching German at initiation level in a virtual environment has posed a number of challenges, at various levels, for both teachers and students. The initial stage of the course was designed, on the one hand, to familiarize the student with the German pronunciation and prosody and, on the other hand, to teach vocabulary and basic day-to-day structures, eg. introduce oneself, greet others, etc. To this end, mainly podcasts and showcasts (figure 2) were made available, containing small tasks for the students to apply the new structures and record short podcasts.

Figure 2

Podcast activity screenshot - German I

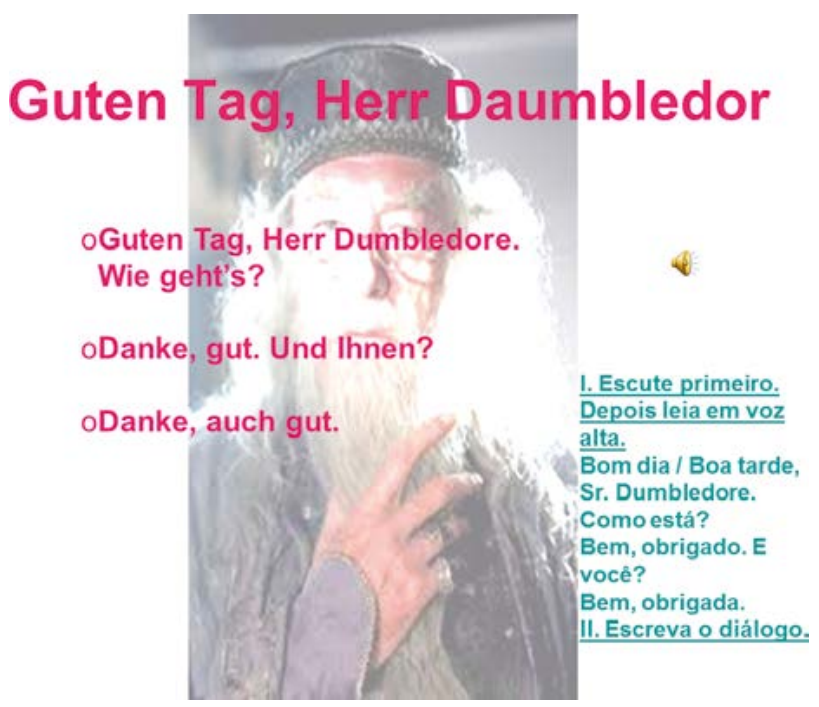

As for the preliminary activities with a focus on phonetics, particular podcasts were introduced to train the students to pronounce sounds that usually pose difficulties to Portuguese native speakers, eg. the pronunciation of $\langle\mathrm{s}>$ in the final position of the syllable or word, the pronunciation of $<\mathrm{h}\rangle$ in the initial position, of $\langle\mathrm{ch}\rangle$ in the final position, and the distinction between long and short vowels (figure 3). Students could listen to podcasts 
repeatedly, and then record their voices in podcast format. They received individual written, as well as MP4 recorded feedback.

\section{Figure 3}

Screenshot of Podcast activity focusing on phonetics - German I

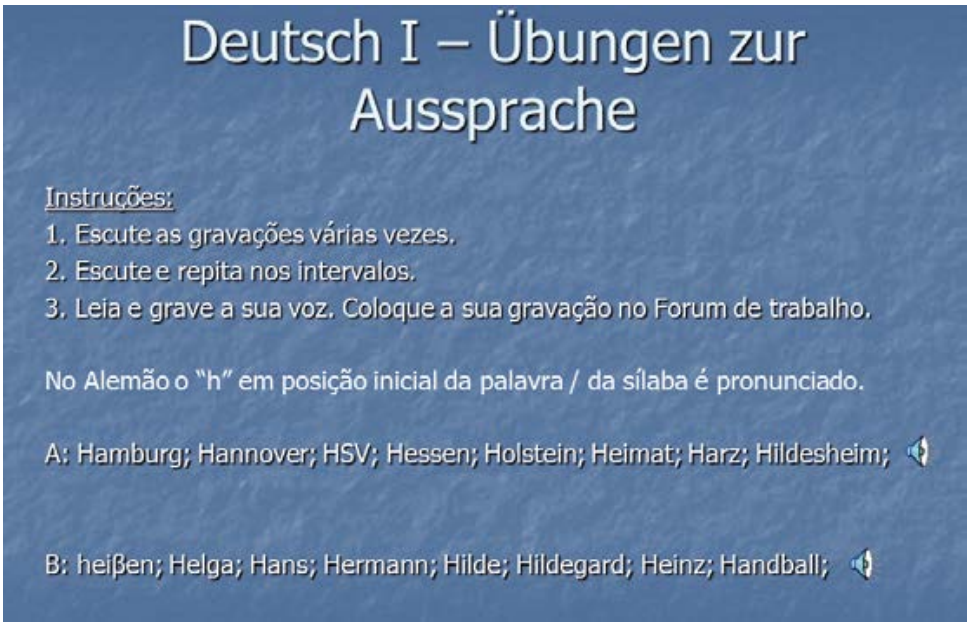

It is through the development of systematic exercises that most technology users realise the merits of these tools. In fact, the offer of formal exercises (one can find a grammatical exercise in minutes), as well as the infinite number of activities and free software available on the Internet, allow for the selection of the occurrences useful for the accomplishment of a task.

After this initial phase without a book, Optimal Al was adopted. Given the fact that we were dealing with beginner-level undergraduate students, and that there was no German-Portuguese glossary, it was necessary to address this situation. We decided to prepare a weekly study guide that included a glossary (the glossary tool in Moodle) with all the new vocabulary, with its translation into Portuguese, as well as the spoken version of the vocabulary. To this end, audio files were integrated into the glossary to allow the students to practise the correct pronunciation of words. These audios with the vocabulary and other audios with the structures of the new forms were also made available separately, in order to be listened to by students, using mobile phones, mp4s or tablets.

To make self-study possible with the adopted book, it was also necessary to devise a study plan for students to follow, making the link between the 
adopted manual, the book of exercises, and the training activities available on each topic. Initially, it was necessary to translate the instructions of the exercises into Portuguese, and to include grammatical explanations in Portuguese.

A series of YouTube videos were provided to train and consolidate the vocabulary and the new structures, as well as the pronunciation.

When learning a foreign language, feedback from the teacher plays an important role for the students, not only so they can assess their oral and written production in the language, but also so they can evaluate their own progress and the adequacy of the learning strategies they adopted, and of course, to enhance their motivation. In a distance learning virtual environment, this feedback from the teacher becomes especially crucial, particularly at an initiation level. We tried, therefore, and as far as possible, to provide individual feedback, recorded and/or in writing, which required constant monitoring of students, and a lot of work.

The main feature of a document introduced in the virtual classroom should not be solely its linguistic function, but also its capacity to trigger the student's discourse and, thus preparing him/her (theme and lexicon) for what comes thereafter. While the students writing the glossary, the interactions in the virtual classroom are not subject to teacher validation (right or wrong answer), but are welcomed as they are and for what they are: spontaneous expressions. The teaching of foreign languages online allows not only for a considerable diversification of teaching materials, but also for the manipulation and construction of a task-pedagogy.

\section{V.2.2. French language curricular units}

The examples presented in the case of the French language curricular units consist of activities carried out in French I, II, III and IV (B1 and B2 levels).

\section{V.2.2.1. Comprehension and production activities}

In online education, multimedia technologies are an excellent support for working on oral and written comprehension. As part of the oral competency, besides giving the sound support for the pedagogical sequence of Task-based teaching (Willis, 2007), they allow students to gradually understand the document: effecting a continuous or occasional disclosure of the transcript, 
discovering lexical elements, facilitating the formulation of hypotheses, etc. For the written comprehension, the text can be adapted: we can change the words by replacing them with others or by linking them, and so forth.

As the French II course corresponds to the CEFR B 1 level, an independent user, in a situation of oral reception, should be able to understand the information contained in a recorded oral document, and in an oral production situation, should be able to expound a contemporary theme in a simple and direct manner, briefly explaining his/her opinion. In 2017, the teacher created two podcasts based on a newspaper article found in Le Parisien ${ }^{l}$ entitled "Les robots les plus marquants ...".

The first podcast was an adaptation of the article, creating an audio document for students to become aware of the situation described, express hypotheses, anticipate and understand the document message content. The second podcast was based on comprehension questions to help students internalize the theme, and to observe and identify its relevant aspects. Finally, students in the oral production situation were encouraged to reflect on the topic described by expressing their opinion (oral with podcast or with Colibri tools), arguing for or against the issue, always justifying their opinions, so as to participate in the learning process with the teacher.

Task-based teaching with multimedia technologies exceeds linguistic production stricto sensu. Technologies can support oral or written production. They may, in some cases, incorporate production as a task (listening, reading, and validating). Technologies allow us to adapt global pedagogical approaches: document exploration; reflection on the linguistic elements identified; and production in context, all as part of a set task. Thus, activities in the virtual classroom transform it into a real-life society. In fact, it is no longer necessary to pretend, as in the "role-play" activities of the communicative approach, instead, a concrete project is produced (through the experiences of social actors), where students can actually engage at different levels, because they are interested in and committed to its accomplishment. To this end, technologies become appropriate: as a source of real data information (Internet search engines, online dictionaries and encyclopaedias, online tools and resources such as Google, Wikipedia, etc.), especially as this coincides with the search patterns of today's students.

The tasks to be carried out that are directly related to the technologies (for example, producing a video) can be shared as supporting documents or made available as the task is constructed (micro-tasks, intermediate productions...), in order to carry it through. With Europe and Portugal

${ }^{1} \mathrm{http} / / / \mathrm{www}$. leparisien.fr/societe/doit-on-craindre-les-robots-27-10-2017-7357347.php 
currently in the midst of an economic crisis, the teacher chose to work on the crisis through YouTube videos. The activity "La crisis" consisted of viewing two videos relating to an interview for a job (figure 4).

\section{Figure 4}

Screenshot of activity proposed to students and of the videos made available *https://www.youtube.com/watch?v=MbMaNjkGIxQ

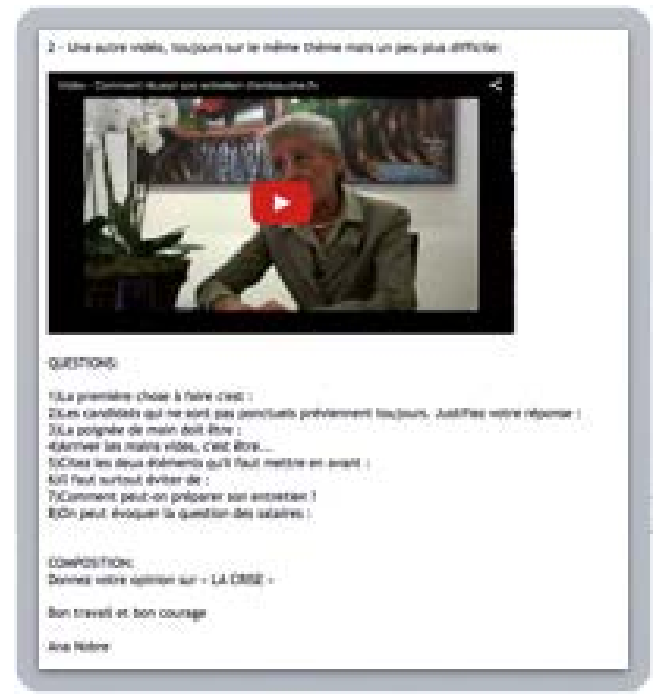

Why video? As the issue is a current and sensitive one for all of us, the choice of the video allows the students to develop knowledge and language skills through demonstration. It enables content standardization, facilitates the transmission of knowledge, and limits the useful information to be memorised. Students can stop the video, and watch it as many times as necessary. In this case, the video, as a complement to the activity, added a more realistic dimension to learning, as this complex teaching/ learning situation, both from the perspective of the vocabulary, and from the harsh reality each one of us has had to experience, became more understandable through the images presented.

To carry out the requested tasks, students submitted their answers orally, uploading them onto the debate forum, where a very active discussion took place, especially taking into account the fact that the students were not only from Portugal, but also from Africa and Brazil. 


\section{V.2.3. English language curricular units}

Podcasts, showcasts and videocasts have been systematically used in the courses to develop the students' competencies at that level, and to promote their written and oral skill acquisition in all areas related to their day-to-day lives and interests.

As the students are all adults, the teacher has attempted to work on themes that may be meaningful and interesting to them, and that may foster their active participation in the virtual classroom.

The podcasts, recorded by the teacher, have a very significant pedagogical impact, in that they enhance teacher-students proximity, creating an emotionally balanced learning environment, thus overcoming the barriers commonly encountered in distance teaching/learning. Students have been noted to make very positive comments and remarks upon hearing their own teacher's voice.

The same can be stated with regard to hearing one another's voices (students) and personal introductions in English II. The students' reaction is always very positive and it encourages collaborative work and mutual support in their learning process.

The CEFR specifies that the task should not be solely of a linguistic nature but rather a coordinated set of collective actions that tend towards an objective in a given context, for a stipulated outcome. As the action-oriented approach does not consider language as an end in itself, and because it does not use only linguistic knowledge to accomplish the task, it incorporates a much broader set of skills and strategies from the very first moments of the design of the project, of which technologies are an enabling part.

In English I, podcasts have been used to train oral comprehension and written production skills, as in the Figure 5. After listening to the podcast recorded by the teacher, students are given some written exercises and are required to write down their answers, thus training their oral comprehension and written production competencies. Students are then given an answer key so they can check their answers and then clear their doubts with the teacher in the topic forum.

Wikis are also used to further develop their written production competencies and to promote collaborative work, as in the Figure 6. The teacher always gives timely feedback, and makes all necessary corrections in this type of activity. Hot Potatoes-type activities have also been used in both courses to train specific aspects of the syllabus. The skills that each student uses to accomplish the task are perfectly compatible with multimedia technologies, both during the project phase (task presentation, difficulty, 
implementation, strategies, etc.), and during the design phase (search for documents, information, "physical" construction of the project, etc.), and during the final phase of presentation of the results (sharing in the virtual classroom, in the network, etc.).

\section{Figure 5}

Screenshot of oral comprehension activity proposed to students

PODCAST 1 - Describing a Person

Here are some technical instructions in Portuguese:

Clique no nome do ficheiro ou na pequena seta que se encontra ao lado: abrir-se-á o Windours Media Player e começará a ouvir, clicando na seta.

Para gravar o documento Sudio, clique no botJ̃o direito do rato no nome do ficheiro. Seleccione entao "guardar destino como..." e grave na pasta onde tem os documentos da unidade curricular. Poderá abri-lo mais tarde, clicando no nome do ficheiro.

Boa audição!

describine.jerson.mos

Figure 6

Screenshot of activity proposed to develop the students' written production and their collaborative work.

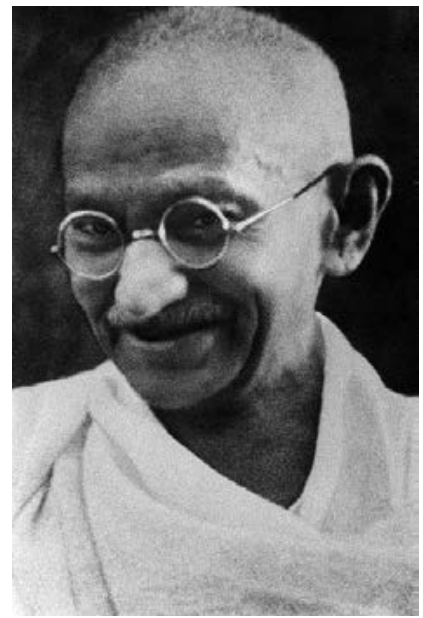

Showcasts have been used to train various competencies simultaneously, e.g. oral comprehension, pronunciation, intonation, prosody, and written production, as the teacher creates a PowerPoint document, records the text, which the student can listen to while he reads it himself/herself, as in the 
figure 7 and 8. Students are also required to record their own voices, and share their podcasts with the rest of the class. Before they are given this task, they are expected to listen to a dialogue between two of their teachers, in which they introduce themselves.

\section{Figure 7}

Screenshot of oral comprehension/written production activity showcast SHOWCAST - SCOTS IN SWEDEN

Dear Students,

Please listen to the recording while following the written text. Then answer the questions, and finally, check your answers

Enjoy $|\mathrm{t}|$

SCOTS_IN_SWEDEN_UPSET.PPE

Figure 8

Screenshot of oral comprehension/written production activity showcast

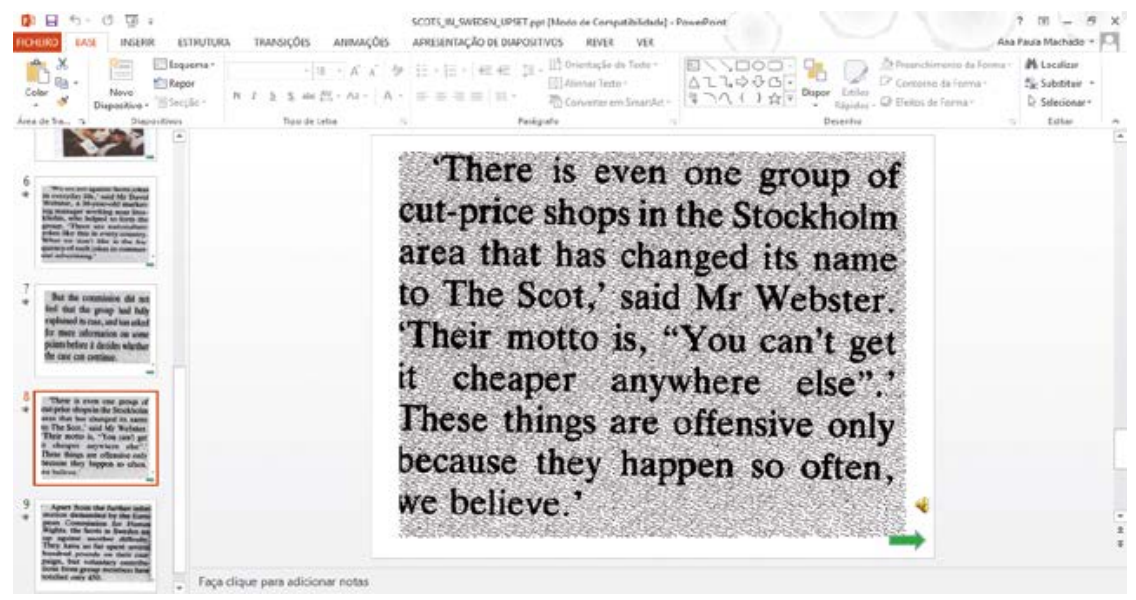

Videos have also been made and used to train certain aspects of the language, in an entertaining and visually-appealing manner, where a Canadian-born student (English native speaker) introduces herself to the rest of the class, talks about her daily activities, and compares lifestyles between Canada and Portugal, thus making use of a real-situation context to foster the students' interest in the language. 
The students reacted very positively to these training activities, where teaching-learning solutions implemented through podcasts, videocasts, and showcasts were adopted. They proved to have effectively assimilated lexical and grammatical elements that, until then.

\section{Oral activities in e-learning: Impact}

This positive feeling is shared by students of courses of foreign languages, as is demonstrated, for example, in the words of a student of German II when he writes: "[...] Online lernen war für mich eine ganz neue anfangs erfahrung, und ich muss sagen dass es sehr einfach mit ihnen war. Ich hatte sie die sensation persönlich zu kennen. [...] “.” [...] (Online study was a completely new experience for me, and I must say it was very easy with you [the teacher]. I had the feeling that I knew you [the teacher] personally. [...].

Students revealed no substantial difficulty in the implementation of these new teaching-learning strategies that also enable them to develop technological skills, always with the teacher's support. Furthermore, and in particular, visualizing their production and that of their classmates' not only pleases them, but also allows them to follow their own progress, thus developing reflective skills.

Thus, from the combination of UAb's Pedagogical Model with the CEFR, and with the set of references relating to digital technology resources, there emerges an innovative pedagogical approach, adequate both to teaching and learning a foreign language, and to today's society. With this new approach, we aim to equip students with the written and oral competencies needed in real life. That is, more specifically, our educational proposal relies on activities based on practice, and on problem resolution in specific situations, always contextualized, and closely linked to the lives of students, and to the community in which they live, thus embodying a project pedagogy.

\section{VI.1. First results from a survey}

In the project "Teaching/Learning Foreign Languages online", a questionnaire was developed in which we tried to identify strategies that are conducive to the success of all UAb students enrolled in 1st cycle foreign language courses. Thus, during the second semester of the 2016/17 school year, between May and June 2017, the survey was made available online to 32 German students, 95 French students and 426 English students, levels II, 
IV and V (B1 and B2 levels). In total, 322 students answered. This survey was made up of 3 parts, the first being the characterization of the foreign language UCs and the course attended and the personal data (sex, age, place and country of residence). The second part of the inquiry contained general questions concerning both the student's computer resources and some of their habits as Internet users.

The third part of the survey focused on questions that asked students opinions about:

- Technical quality

- Degree of difficulty and proficiency

- Clarity of instructions

- Usefulness of the audio and multimedia resources placed by teachers on the Moodle platform of the UAb, in virtual classrooms

- Relevance to learning

- Facilitation of learning

- Motivation for learning the foreign language

The analysis of first data in the third part shows that most respondents $(63 \%)$ consider sound quality in audio or multimedia files to be good (only $1 \%$ think it was bad and $35 \%$ consider it to be excellent). The vast majority of respondents $(80 \%)$ said they heard them all and $(81 \%)$ agree that they listened to them several times to train their listening skills. The vast majority of respondents considered that multimedia resources were sufficient (83\%) and motivated (89\%), facilitators of learning (92\%) and improved not only the comprehension of oral discourse (91\%) as well as the level of knowledge of the foreign language in question (89\%). It is interesting to note that the great majority $(90 \%)$ also agree that it was important to have heard the voice of the teacher and the colleagues.

General learning activities and materials were considered appropriate for the intended educational objectives. The presence of multimedia content is considered as the key to success in the educational process and the distinctive feature of education online and e-learning.

VI.2. Multimedia technologies and task-based teaching: Learning how to learn

As we have seen, the use of these communication tools has allowed for the quality integration of training activities in the daily life of UAb students. This has been a constant concern of the teaching staff of LE@d's current foreign language online teaching-learning research project - “@ L2L - Open 
Language Teaching and Learning", and a challenge to which we expect to continue responding. Thus, the high level of interest and the successful participation of students in these activities, as well as the practical results obtained seem to prove the effectiveness of the policies followed, and of the educational means utilized.

The strategies adopted by higher education institutions to promote the development of oral comprehension and production skills, as well as their assessment, in foreign language teaching within the virtual system are multiple, but they do not always fully depend on Web 2.0 tools. At Universidade Aberta, however, we try to find solutions that enable the acquisition of these skills through the preponderant use of these tools, taking into account the criteria of relevance, comprehensiveness and accessibility. Therefore, and combining the four fundamental principles of the unprecedented virtual pedagogical model that we follow (Pereira et al., 2007) with the fact that we do not want to overload our students with additional financial costs, we promote, as much as possible, the use of free tools.

The response of students to this multimedia material has been very positive, and they have even openly expressed their liking, and participated more significantly in the virtual classroom. This greater involvement and commitment of students led to their more proactive attitude, especially as they have become co-creators of learning contents and materials.

So far, the use of such tools has confirmed that oral comprehension and production are not inconsistent with e-learning, on the contrary, they ensure greater proximity between teachers and students, and between the students themselves, who meet only online to exchange relevant experiences orally, which now have become part of their foreign language teaching-learning process in the virtual environment.

This last point is particularly relevant because the CEFR calls "knowledge" a learning process, focusing in particular on the skills used in learning.

\section{Final considerations}

In short, the innovative strategies and solutions implemented and tested under the first project can be considered positive. It no doubt motivates us to give continuity to our work and to our research in this field of teachinglearning foreign languages online. It tends to become an interesting, effective, and appealing alternative, in an era where the diversification of realities 
demands an increasingly immediate and effective answer to meet the needs of a globalized society.

The research carried out seems to show that the use of multimedia technology is a good methodology for the practice and evaluation of oral communication in online education, enabling the production of texts as diverse as readings, comments, dialogues, simulations, digital stories, among others, and it is able to overcome the constraints of non-face-to-face teaching, ensuring the time flexibility characteristic of this type of education, since digital resources, such as podcasts and showcasts, for example, can be created and shared asynchronously.

The use of multimedia technology enables active, self-regulated learning, focused on learners, and respecting their individual pace of learning, thus promoting the development of oral and written communication competencies.

As technologies are increasingly present in the teaching / learning of foreign languages, at different pedagogical and interactivity levels, it appeared relevant to us to reformulate its various uses in the action-oriented approach drawn in the CEFR and in UAb's pedagogical model.

Both in the general theoretical context of task-pedagogy and in most phases of the educational process within the virtual classroom, the presence of technological tools in the foreign language virtual classroom is perfectly consistent with the CEFR's ideas.

Moreover, in an e-learning education system, such as UAb's, where written communicative interaction is always present, these pedagogicaldidactic strategies allow for a closer proximity, thus overcoming physical distance, and creating emotional ties in the virtual classroom, which are no doubt encouraging in online foreign language teaching-learning "Anywhere in the World".

\section{Bibliography}

Bailly, Sophie. "Supporting Autonomy Development in Online Learning Environments: What Knowledge and Skills do Teachers Need?". In Luzon, M. J, Ruiz, M. N. \&. Villanueva, M L. (dir.). Genres Theory and New Literacies: Applications to Autonomous Language Learning. Newcastle upon Tyne : Cambridge Scholars Publishing. (2010). pp. 81-100.

Barbot, Marie José. \& Jacquinot-Delaunay, Geneviève. «Des ressources pédagogiques aux usages : vers l'autonomisation de l'étudiant ?». In Jacquinot-Delaunay, G. \& Fichez, É. (dir.). (2008). pp. 143-178.

Boutinet, Pierre. «Les pratiques d'accompagnement individuel, entre symbole et symptôme». Carriérologie, vol. 9. (2003). pp. 67-78. 
Cardoso, Teresa, Gottsche, Katja, Machado, Ana Paula, Nobre, Ana. Ensinar e Aprender Línguas Estrangeiras na Universidade Aberta: exemplos de práticas comunicativas online. In P. Dias, D. Moreira \& A. Quintas-Mendes (Org.). Práticas e cenários de inovação em Educação Online. Lisboa, Universidade Aberta, 2016.

Cardoso, Teresa \& Matos, Filipa. "Learning Foreign Languages in the Twenty-First Century: An Innovating Teletandem Experiment Through Skype". In A. Moreira, O. Benavides \& A. J. Mendes (Org.). Media in Education. Results from the 2011 ICEM and SIIE Joint Conference (2013). (pp.87-95). New York: Springer (ISBN print: 978-1-4614-3174-9; ISBN online: 978-1-4614-3175-6)

Cardoso, Teresa, Göttsche, Katja, Machado, Ana Paula \& Nobre, Ana. Podcasts e showcasts no ensino superior a distância: cinco anos a inovar no ensinoaprendizagem de línguas estrangeiras online. In M. J. Gomes, A. J. Osório, A. Ramos, B. D. Silva \& L. Valente (Org.). Atas da VIII Conferência Internacional de TIC na Educação "Challenges 2013: Aprender a qualquer hora e em qualquer lugar» (2013). (pp.667-674). Instituto de Educação da Universidade do Minho (ISBN: 978-989-97374-2-6).

Chapelle, Carole. "Autonomy meets individualization in CALL". Mélanges - TIC et autonomie dans l'apprentissage des langues, $\mathrm{n}^{\circ}$ 28. (2006). pp. 77-88.

Chateau, Anne \& Bailly, Sophie. "Learning in a language centre: A new kind of 'doit-yourself'?". Language Learning in Higher Education, vol. 2, n 2. (2013). pp. 371-383. DOI : 10.1515/cercles-2012-0020

Council of Europe, Common European Framework of Reference for Languages: Learning, Teaching, Assessment. Cambridge University Press. 2011.

Debaisieux, Jeanne Marie. \& Boulton, Alex (dir.), Mélanges - TIC et autonomie dans l'apprentissage des langues, $\mathrm{n}^{\circ}$ 28. (2006). http://www.atilf.fr/spip. php?rubrique 579

Holec, Henri .»Qu'est-ce qu'apprendre à apprendre ?». Mélanges. (1990). pp. 75-87. http://www .atilf.fr/spip.php?article3658

Little, David. “Autonomy and autonomous learners". In Byram, M. (dir.).Routlegde encyclopedia of language teaching and learning. London : Routledge. (2000). pp. 69-72.

Moura, Adelina, Carvalho, Ana Amélia , Podcast: Potencialidades na Educação. Prisma.com. , 2006.

Nobre, Ana \& Cardoso, Teresa. Educação online e línguas estrangeiras: ferramentas digitais gratuitas para desenvolver a oralidade em francês. Indagatio Didactica, 7 (1), (2015). 165-175. CIDTFF - Centro de Investigação em Didática e Tecnologia na Formação de Formadores, Universidade de Aveiro (ISSN: 16473582), http://revistas.ua.pt/index.php/ID/article/view/3461/3206.

Paul, Maela , L'accompagnement : une posture professionnelle spécifique. Paris : L'Harmattan, 2004.

Pereira, Alda, Quintas-Mendes, António, Morgado, Lina, Amante, Lúcia, Bidarra, José. Universidade Aberta's Pedagogical Model for Distance Education. A University for the Future. Lisboa, Universidade Aberta, 2007. 
Portine, Henri,»L'autonomie de l'apprenant en questions». Apprentissage des langues et systèmes d'information et de communication (Alsic), vol. $1, \mathrm{n}^{\circ} 1$. (1998). pp. 73-77. http://alsic.revues.org/1466

Rivens Mompean, Annick. «Le CRL - Un espace privilégié pour aller vers 1〉autonomie». Les langues modernes, vol. 3. (2012). pp. 69-74.

Salema, Luís \& Cardoso, Teresa. Curriculum e novos media na educação em línguas. Em J. F. Matos, N. Pedro, A. Pedro, P. Patrocínio, J. Piedade \& S. Lemos (Org.). Atas do II Congresso Internacional TIC e Educação «Em direção à educação 2.0»-ticEDUCA (2012). (pp.1425-1442). Instituto de Educação da Universidade de Lisboa (ISBN: 978-989-96999-8-4).

Willis, Dave \& Willis, Jane, Doing Task-based teaching, OUP. Annexes, 2007.

\section{About the author}

ANA MARIA DE JESUS FERREIRA NOBRE (Ana.Nobre@uab.pt), PhD, works at the Education Department, Universidade Aberta (Portugal). After living and studying in Paris, she currently teaches at Universidade Aberta where she has taught since 1998, having previously been a Professor at the Sorbonne University, Paris. She completed a PhD in Didactologie des langues et des Cultures from the University Sorbonne Paris III. She is dedicated to the teaching of foreign languages in eLearning, to digital resources for learning in online environments and recently to the didactic eLearning and gamification in education. She was coordinator of the project "Teaching / learning languages online" and "@ L2L - Open Language Teaching and Learning”, and researcher of @ ssess project of the Distance Education Laboratory and eLearning (FCT, 2010-2013) where she investigated the problem of digital alternative assessment of orality. 


\title{
Multimedia technologies and online task-based foreign language teaching-learning
}

\author{
Ana Maria de Jesus Ferreira Nobre*
}

doi: http://dx.doi.org/10.18543/tjhe-5(2)-2018pp75-97

Received: 09.05.2018

Accepted: 28.05 .2018

\section{Copyright}

Copyright for this article is retained by the Publisher. It is an Open Access material that is free for full online access, download, storage, distribution, and or reuse in any medium only for noncommercial purposes and in compliance with any applicable copyright legislation, without prior permission from the Publisher or the author(s). In any case, proper acknowledgement of the original publication source must be made and any changes to the original work must be indicated clearly and in a manner that does not suggest the author's and or Publisher's endorsement whatsoever. Any other use of its content in any medium or format, now known or developed in the future, requires prior written permission of the copyright holder. 